\title{
Synthesis, thermal behavior, and spectroscopic study of the solid nalidixate of selected light trivalent lanthanides
}

\author{
Marcos Vinícius Dobies Návia ${ }^{1}$ Diogo Alves Gálico² • Flávio Junior Caires ${ }^{3} \cdot$ José Marques Luiz • \\ Ronaldo Spezia Nunes ${ }^{1}$ (1)
}

Received: 16 September 2017 / Accepted: 25 January 2018/Published online: 9 February 2018

(C) Akadémiai Kiadó, Budapest, Hungary 2018

\begin{abstract}
Solid-state [ $\left.\mathrm{Ln}(n a l)_{3}\right] \cdot n \mathrm{H}_{2} \mathrm{O}$ compounds, where $\mathrm{Ln}$ represents light trivalent lanthanide (La to Sm, except Pm), nal is nalidixate $\left(\mathrm{C}_{12} \mathrm{H}_{11} \mathrm{~N}_{2} \mathrm{O}_{3}\right)$, and $n$ is the number of water molecules, were synthesized. Characterization and investigation were made by means of complexometry, elemental analysis, powder X-ray diffraction, Fourier transform infrared, near infrared (NIR) and diffuse reflectance spectroscopies, simultaneous thermogravimetry and differential thermal analysis, and differential scanning calorimetry. The dehydration process occurs in a single step up to $453 \mathrm{~K}$. The final temperature of dehydration decreases from $\operatorname{Pr}(\mathrm{III})$ to $\mathrm{Sm}(\mathrm{III})$, and the thermal stability of anhydrous compounds increases from $\mathrm{La}(\mathrm{III})$ to $\mathrm{Sm}$ (III) (except $\mathrm{Ce}$ ), and these behaviors are related to the decrease in the ionic radius of the lanthanide ion. The thermal decomposition of the anhydrous compounds occurs in three, four, or five consecutive steps, with formation of the respective oxides $\mathrm{CeO}_{2}, \mathrm{Pr}_{6} \mathrm{O}_{11}$, and $\mathrm{Ln}_{2} \mathrm{O}_{3}(\mathrm{Ln}=\mathrm{La}, \mathrm{Nd}$, and $\mathrm{Sm})$ as final residues. The results also provide information concerning the composition and thermal behavior of these compounds. Spectroscopic studies in the UV-Vis and NIR regions provide information about the characteristics $4 f-4 f$ transitions for the $\operatorname{Pr}(\mathrm{III}), \mathrm{Nd}(\mathrm{III})$, and $\mathrm{Sm}$ (III) compounds, as well as the NIR region characteristic overtone and combination bands of the compounds.
\end{abstract}

Keywords Nalidixic acid · Nalidixates - Trivalent lanthanides - Synthesis - Characterization · Thermal study · Spectroscopic study

\section{Introduction}

There are 15 lanthanide elements, from lanthanum $(Z=57)$ to lutetium $(Z=71)$, and they are also known as $4 f$ elements because their electrons have a partial occupation of the $4 f$ shell. Due to the electronic configuration in the $4 f$ orbitals, the chemical properties lead to the formation of compounds with interesting features for application

Electronic supplementary material The online version of this article (https://doi.org/10.1007/s10973-018-7042-0) contains supplementary material, which is available to authorized users.

Ronaldo Spezia Nunes

spezia@feg.unesp.br

1 Faculdade de Engenharia, Universidade Estadual Paulista (UNESP), Guaratinguetá, SP, Brazil

2 Instituto de Química, Universidade Estadual de Campinas (UNICAMP), Campinas, SP, Brazil

3 Faculdade de Ciências, Universidade Estadual Paulista (UNESP), Bauru, SP, Brazil in several research fields [1, 2], such as compounds with magnetic characteristics, luminescent properties, and compounds with biological applications [3-15].

A noteworthy feature of lanthanides is the small variation in the atomic radius as the atomic number $(Z)$ increases, due to the increase in the nuclear charge. This effect is called lanthanide contraction [16] and is responsible for the small variations in the chemical properties of these elements, such as the basicity degree. The differences in the basicity degree are mainly reflected in the hydrolysis of the ions, solubility of the salts, thermal decomposition of oxy salts, and formation of complex species $[2,16]$.

Complexes with molecules used as medications have been extensively studied due to their biological and spectroscopic properties. Recent studies on lanthanide complexes with nonsteroidal drugs, such as mefenamic acid, ketoprofen, and oxyphenbutazone, found that they exhibit unique spectroscopic and biological properties with applications in biological and technological fields [17-20]. Complexes with enrofloxacin, ciprofloxacin, norfloxacin, 
ofloxacin, carproxen, amoxicillin, coumarins, and other antioxidants have also been widely studied recently [21-27] and have demonstrated their great potential for application in therapeutic or optical fields.

Nalidixic acid (Hnal) is a white crystalline powder (or pale yellow color) and was one of the first compounds that belong to the quinolone class used as an antibacterial agent [28]. Quinolones are interesting complexing agents for several metal ions [29], and the synthesis and characterization of metal complexes or metal-drug complexes agents are growing and becoming important $[30,31]$.

Recently, Eliseeva et al. [32] studied nalidixic acid complexes with lanthanides in solution. They found that this ligand can sensitize the visible emission of Eu(III), $\mathrm{Tb}(\mathrm{III})$, and $\mathrm{Tm}(\mathrm{III})$ ions, the near infrared emission of $\mathrm{Yb}(\mathrm{III})$ and $\mathrm{Nd}(\mathrm{III})$ ions, and both visible and near infrared emissions of $\operatorname{Pr}(\mathrm{III}), \mathrm{Sm}(\mathrm{III}), \mathrm{Dy}(\mathrm{III})$, and Ho(III) ions, showing that nalidixic acid is a versatile ligand in the optical field.

Investigations about trivalent metal quinolones have mostly looked at their biological activities, and few studies have investigated the thermal behavior in the solid state. Given the importance of metal ions in biological systems, the principal aims of this work were the synthesis, thermal behavior characterization, and spectroscopic studies of the nalidixate complexes with light trivalent lanthanides ions.

\section{Experimental}

\section{Materials}

The nalidixic acid- $\mathrm{H}$ nal $\left(\mathrm{C}_{12} \mathrm{H}_{12} \mathrm{~N}_{2} \mathrm{O}_{3}\right)$, sodium nalidixate salt-Nanal $\left(\mathrm{NaC}_{12} \mathrm{H}_{11} \mathrm{~N}_{2} \mathrm{O}_{3}\right)$, and lanthanide oxides $\left(\mathrm{Ln}_{2} \mathrm{O}_{3}: \mathrm{Ln}=\mathrm{La}\right.$, Nd and $\mathrm{Sm}, \mathrm{Pr}_{6} \mathrm{O}_{11}$ and $\mathrm{Ce}\left(\mathrm{NO}_{3}\right)_{3}$. $6 \mathrm{H}_{2} \mathrm{O}$ ) with $99 \%$ purity were obtained from Aldrich and used as received.

\section{Preparation of compounds}

Aqueous solution of Nanal $0.1 \mathrm{~mol} \mathrm{~L}^{-1}$ was prepared by Hnal neutralization with diluted aqueous solution of $\mathrm{NaOH}$, whereupon $\mathrm{pH}$ was adjusted to 8.5 by adding diluted sodium hydroxide or hydrochloric acid solutions. Lanthanide chlorides were prepared from the corresponding metal oxides (except for cerium) by treatment with concentrated hydrochloric acid. The obtained chlorides were dissolved in distilled water, transferred to a volumetric flask, and diluted to obtain ca. $0.1 \mathrm{~mol} \mathrm{~L}^{-1}$ solutions, in which $\mathrm{pH}$ were adjusted to 5.0 by adding diluted sodium hydroxide or hydrochloric acid solutions. Cerium trivalent ion was used as its nitrate, and $0.1 \mathrm{~mol} \mathrm{~L}^{-1}$ aqueous solutions of this ion were prepared by direct weighing of the salt.

The solid-state compounds $\left[\operatorname{Ln}(n a l)_{3}\right]$ were prepared by slowly adding, with continuous stirring, the sodium nalidixate solutions into the respective lanthanide chloride solutions until total precipitation of the compounds. The resulting solutions were heated until almost boiling and kept in a refrigerator for $12 \mathrm{~h}$. After this period, the solutions were carefully removed, more deionized water was added, and a new cycle started (heat and refrigeration). This process was repeated to guarantee the elimination of chloride ions. The precipitates were filtered on Whatman no. 40 filter paper, washed with deionized water until negative test for chloride ions $\left(\mathrm{AgNO}_{3}\right.$ solution), dried at $323 \mathrm{~K}$ in a forced circulation air oven for $12 \mathrm{~h}$, and kept in a desiccator over anhydrous calcium chloride.

\section{Characterization techniques}

In the solid-state compounds, the lanthanide ions, molecules of water, and nalidixate contents were determined from TG curves. The carbon, hydrogen, and nitrogen contents were determined by microanalytical procedures using a CHNS/O Elemental Analyzer from Perkin-Elmer (model 2400 Series II CHNS/O) and by calculations based on the mass losses of the TG curves.

The lanthanide ions were also determined by complexometry with standard EDTA solution [33, 34]. A certain quantity of each compound was weighted in an analytical balance and heated in an oven to produce the respective oxides. The oxides were dissolved with concentrated hydrochloric acid and quantitatively transferred to a volumetric flask. Aliquots of this solution were titrated from standard EDTA solution in ammonium acetate buffer and xylenol orange as a visual indicator.

Powder-XRD measurements were done on a Siemens D-5000 X-ray diffractometer, employing $\mathrm{CuK} \alpha$ radiation $(\lambda=1.54184 \AA)$ and a setting of $40 \mathrm{kV}$ and $20 \mathrm{~mA}$.

The attenuate total reflectance infrared spectra for sodium nalidixate, as well as for its metal ion compounds, were run on a Nicolet iS10 FTIR spectrophotometer, using an ATR accessory with Ge window.

Simultaneous TG-DTA curves were obtained with a Thermogravimetric Analyzer Q2960 system from TA Instruments. The purge gas was air with a flow rate of $100 \mathrm{~mL} \mathrm{~min}{ }^{-1}$, a heating rate of $20 \mathrm{~K} \mathrm{~min}^{-1}$, and samples weighing about $5 \mathrm{mg}$. Alumina crucibles were used for recording the TG-DTA curves.

The DSC curves were recorded using a DSC Q10 modulus (TA instruments) under an air flow of $50 \mathrm{~mL} \mathrm{~min}^{-1}$ and at a heating rate of $20 \mathrm{~K} \mathrm{~min}^{-1}$. The sample masses were about $2 \mathrm{mg}$, and covered aluminum crucibles with a perforated lid in the center $(\phi=0.7 \mathrm{~mm})$ 
were employed during the analysis. DSC modulus was calibrated using indium metal $(99.99+\%)$ for temperature and enthalpy.

Near infrared spectra (NIR) were collected using a Thermo Scientific Antaris II spectrophotometer by reflectance, within the $10,000-4000 \mathrm{~cm}^{-1}$ range.

Diffuse reflectance (DR) spectra were acquired using a Varian Cary 5000 spectrophotometer within the 200-1000 nm range with spectral resolution of $0.5 \mathrm{~nm}$.

\section{Results and discussion}

\section{Nalidixic acid (Hnal) and sodium nalidixate (Nanal $\cdot \mathrm{H}_{\mathbf{2}} \mathbf{O}$ )}

The TG-DTA curves of Hnal are shown in Fig. 1a. The TG curve shows that $\mathrm{Hnal}$ is thermally stable until $498 \mathrm{~K}$, where its melt occurs, with peak temperature of $501.6 \mathrm{~K}$ in the DTA curve, followed by the complete thermal decomposition in a single step $(\Delta m=92.54 \%)$ between 498 and $631 \mathrm{~K}$, and the corresponding exothermic broad peak at $622 \mathrm{~K}$. After this step, there is only one small event $(\Delta m=6.12 \%)$ corresponding to the carbonaceous residue burns.

For sodium nalidixate $\left(\mathrm{Nanal} \cdot \mathrm{H}_{2} \mathrm{O}\right)$, the TG-DTA curves in air atmosphere, in Fig. 1b, show mass losses in three steps and thermal events corresponding to these losses. The first mass loss until $442 \mathrm{~K}$, with a corresponding weak endothermic peak in DTA at $431 \mathrm{~K}$, is due to dehydration. The anhydrous compound is stable up to $557 \mathrm{~K}$. Between 557 and $973 \mathrm{~K}$, thermal decomposition occurs in two steps with formation of sodium carbonate, with 55.96 and $18.46 \%$ respective mass losses. In these steps, the DTA curve shows two exothermic peaks, one centered at $588 \mathrm{~K}$ (broad) and another around $935 \mathrm{~K}$, which are attributed to the decomposition and oxidation of organic matter, respectively.

The DSC curve of (Hnal) in Fig. 1a* shows the peak temperature and the enthalpy of fusion of $502.8 \mathrm{~K}$ $\left(T_{\text {onset }}=501.1 \mathrm{~K}\right)$ and $36.06 \mathrm{~kJ} \mathrm{~mol}^{-1}$, respectively. The DSC curve of Nanal $\mathrm{H}_{2} \mathrm{O}$ is shown in Fig. 1b*. The dehydration process occurred between 386 and $438 \mathrm{~K}$, and the enthalpy related with this process was evaluated in $54.6 \mathrm{~kJ} \mathrm{~mol}^{-1}$. After this process, a small phase transition, probably a crystalline transition, can be observed at $463 \mathrm{~K}$ $\left(0.58 \mathrm{~kJ} \mathrm{~mol}^{-1}\right)$, and in the sequence, the thermal decomposition occurred in accordance with TG-DTA curve.

\section{Lanthanide complexes}

\section{Analytical results}

The analytical and thermoanalytical data shown in Table 1 establish the stoichiometry of the compounds, which is in agreement with general formula $\left[\mathrm{Ln}(n a l)_{3}\right] \cdot n \mathrm{H}_{2} \mathrm{O}$, where $\mathrm{Ln}$ represents trivalent lanthanides ions (from $\mathrm{La}$ to $\mathrm{Sm}$, except $\mathrm{Pm}$ ), nal is nalidixate anion, and $n=5$ (La) and 6 (Ce, Pr and Sm). Thus, the features of each compound are discussed on the base of their similar thermal profiles.
Fig. 1 a TG-DTA curves of Hnal ( $m=4.9879 \mathrm{mg})$; $\mathbf{a}^{*}$ DSC curve of Hnal $(m=2.585 \mathrm{mg})$; b TG-DTA curves of Nanal $\cdot \mathrm{H}_{2} \mathrm{O}$ $(m=3.3398 \mathrm{mg})$ and $\mathbf{b}^{*}$ DSC curve of Nanal $(m=2.0270 \mathrm{mg})$
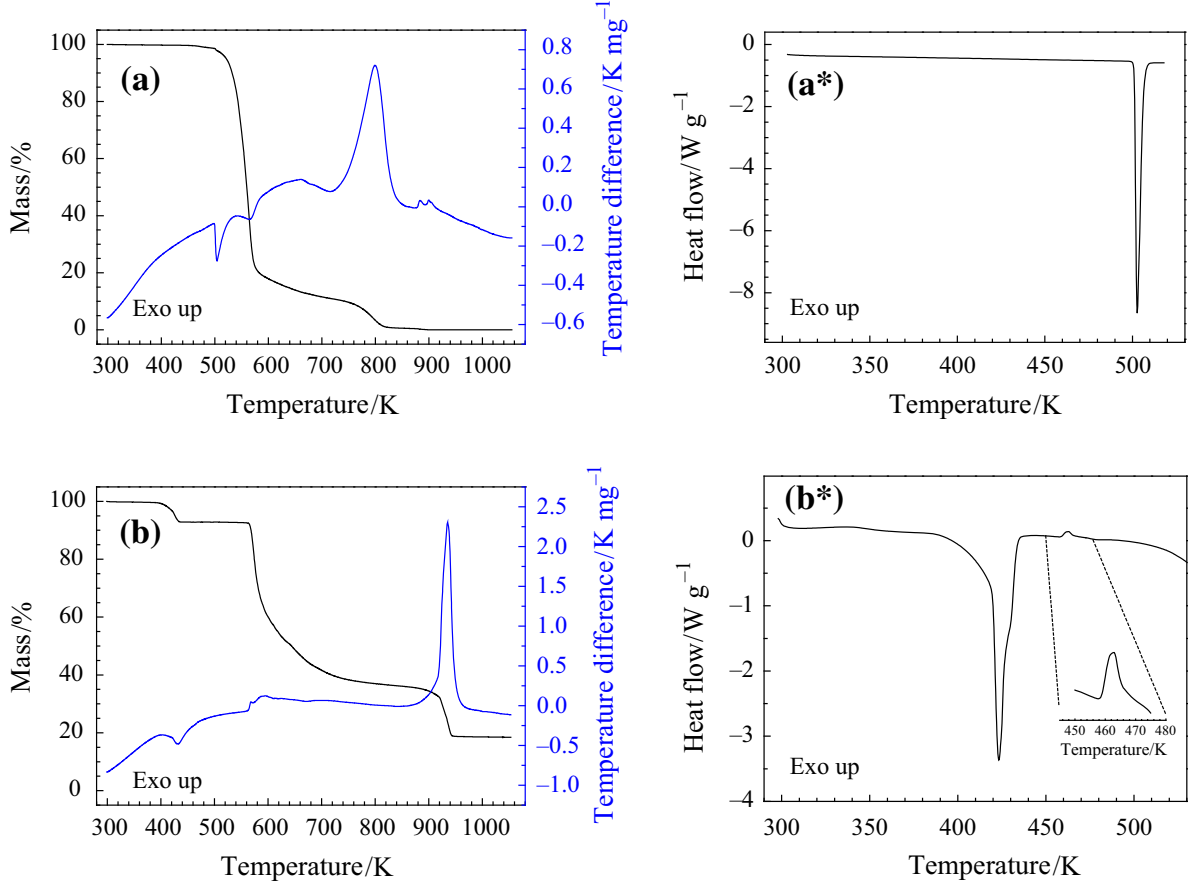


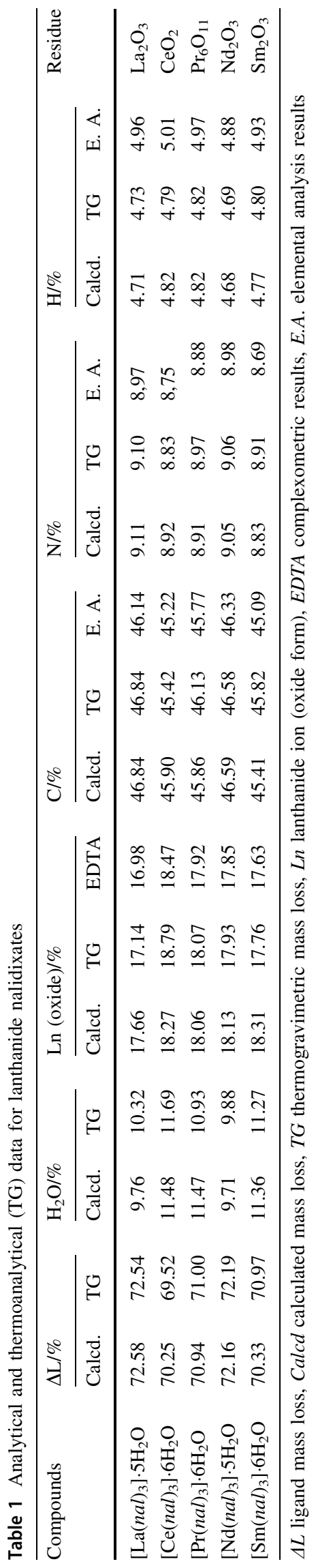


The values obtained from TG, EA, and EDTA analyses are in agreement with the theoretical ones, confirming the stoichiometry of the compounds. As the thermal behavior depends on the nature of the lanthanide ion, the discussion about the thermal events of the compounds is grouped by the similar profiles.

Recently, Eliseeva et al. [32] by means of spectroscopic analysis demonstrated that the lanthanide (III) nalidixate complexes possess one coordinated water on their structures. Consequently, the remaining water molecules in our compounds are located in the outer coordination sphere, and the lanthanide (III) ion has a coordination number of 7 . This coordination number also occurs in other lanthanide carboxylate complexes based in pharmaceutical compounds such as ketoprofen [35] and naproxen [36].

\section{Thermal analysis}

The simultaneous TG-DTA curves of the light trivalent lanthanide compounds show mass losses in two (Ce), four (Pr), and five ( $\mathrm{La}, \mathrm{Nd}$, and $\mathrm{Sm}$ ), with consecutive and/or overlapping steps with the respective thermal events

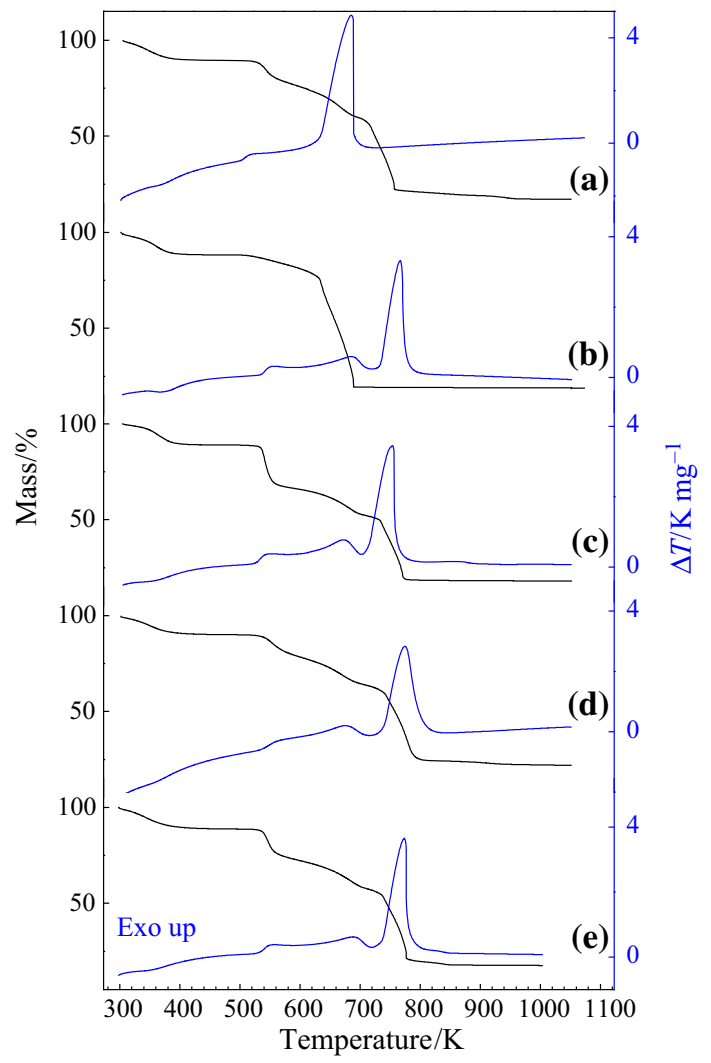

Fig. 2 TG-DTA curves of the nalidixate compounds: (a) [La( $\left.\mathrm{nal})_{3}\right]$. $5 \mathrm{H}_{2} \mathrm{O} \quad(m=5.2692 \mathrm{mg})$, (b) $\left[\mathrm{Ce}(n a l)_{3}\right] \cdot 6 \mathrm{H}_{2} \mathrm{O} \quad(m=5.5890 \mathrm{mg})$, (c) $\quad\left[\operatorname{Pr}(n a l)_{3}\right] \cdot 6 \mathrm{H}_{2} \mathrm{O} \quad(m=5.5186 \mathrm{mg}), \quad(\mathrm{d}) \quad\left[\mathrm{Nd}(n a l)_{3}\right] \cdot 5 \mathrm{H}_{2} \mathrm{O}$ $(m=5.4766 \mathrm{mg})$ and e $\left[\mathrm{Sm}(\mathrm{nal})_{3}\right] \cdot 6 \mathrm{H}_{2} \mathrm{O}(m=5.4252 \mathrm{mg})$ corresponding to these losses. Three patterns of thermal behavior can be observed in Fig. 2 .

\section{Lanthanum, neodymium, and samarium nalidixates}

The simultaneous TG-DTA curves for the lanthanum, neodymium, and samarium compounds are shown in Fig. 2a, d, and e, respectively. For both compounds, the first mass loss between 298 and $426 \mathrm{~K}$ associated with a broad peak in DTA curve at $358 \mathrm{~K}(\mathrm{La}), 360 \mathrm{~K}(\mathrm{Nd})$, and $354 \mathrm{~K}(\mathrm{Sm})$ is due to dehydration with loss of $5 \mathrm{H}_{2} \mathrm{O}$ $($ Calcd. $=9.76 \% ; \quad \mathrm{TG}=10.32 \%), \quad 5 \mathrm{H}_{2} \mathrm{O}$ (Calcd. $=9.71 \% ; \quad \mathrm{TG}=9.88 \%), \quad$ and $\quad 6 \mathrm{H}_{2} \mathrm{O}$ $($ Calcd. $=11.36 \% ; \mathrm{TG}=11.27 \%)$, respectively.

The anhydrous compound is stable up to $498 \mathrm{~K}(\mathrm{La})$, $505 \mathrm{~K}(\mathrm{Nd})$, and $511 \mathrm{~K}(\mathrm{Sm})$, where a decomposition process occurs in four consecutive and/or overlapped steps between 508-568, 568-689, 689-765, and 765-1051 K (La); 505-577, 577-695, 695-837, and 837-1216 K (Nd); and 511-573, 573-712, 712-800, and 800-1003 K (Sm), with mass losses of $10.47,18.52,38.73$, and $4.64 \%$ (La); $9.24,15.88,40.60$, and $6.47 \%(\mathrm{Nd})$; and $14.28,16.74$, 37.85 , and $2.10 \%(\mathrm{Sm})$, which are attributed to the thermal decomposition and oxidation of the organic material.

Table 2 Temperature range $(\theta)$, mass loss $(\Delta m)$, and peak temperature $\left(T_{\mathrm{p}}\right)$ observed for each stage in the TG-DTA curves

\begin{tabular}{|c|c|c|c|c|c|}
\hline \multirow[t]{2}{*}{ Compounds } & \multicolumn{5}{|l|}{ Steps } \\
\hline & $1^{\circ}$ & $2^{\circ}$ & $3^{\circ}$ & $4^{\circ}$ & $5^{\circ}$ \\
\hline \multicolumn{6}{|c|}{$\left[\mathrm{La}(n a l)_{3}\right] \cdot 5 \mathrm{H}_{2} \mathrm{O}$} \\
\hline$\theta / \mathrm{K}$ & $305-408$ & $498-568$ & $568-689$ & $689-765$ & $765-1051$ \\
\hline$T_{\mathrm{p}} / \mathrm{K}$ & $358^{\mathrm{a}}$ & $545^{\mathrm{b}}$ & $672^{\mathrm{b}}$ & $754^{\mathrm{b}}$ & - \\
\hline$\Delta m / \%$ & 10.50 & 10.47 & 18.52 & 38.73 & 4.64 \\
\hline \multicolumn{6}{|c|}{$\left[\mathrm{Ce}(n a l)_{3}\right] \cdot 6 \mathrm{H}_{2} \mathrm{O}$} \\
\hline$\theta / \mathrm{K}$ & $301-432$ & $497-724$ & & & \\
\hline$T_{\mathrm{p}} / \mathrm{K}$ & $371^{\mathrm{a}}$ & $685^{\mathrm{b}}$ & & & \\
\hline$\Delta m / \%$ & 11.69 & 69.52 & & & \\
\hline \multicolumn{6}{|c|}{$\left[\operatorname{Pr}(n a l)_{3}\right] \cdot 6 \mathrm{H}_{2} \mathrm{O}$} \\
\hline$\theta / \mathrm{K}$ & $303-453$ & $500-570$ & $570-701$ & $701-802$ & \\
\hline$T_{\mathrm{p}} / \mathrm{K}$ & $378^{\mathrm{a}}$ & $559^{\mathrm{b}}$ & $685^{b}$ & $766^{\mathrm{b}}$ & \\
\hline$\Delta m / \%$ & 10.93 & 21.59 & 14.62 & 34.79 & \\
\hline \multicolumn{6}{|c|}{$\left[\mathrm{Nd}(n a l)_{3}\right] \cdot 5 \mathrm{H}_{2} \mathrm{O}$} \\
\hline$\theta / \mathrm{K}$ & $301-419$ & $505-577$ & $577-695$ & $695-837$ & $837-1216$ \\
\hline$T_{\mathrm{p}} / \mathrm{K}$ & $360^{\mathrm{a}}$ & $533^{\mathrm{b}}$ & $675^{b}$ & $774^{\mathrm{b}}$ & - \\
\hline$\Delta m / \%$ & 9.88 & 9.24 & 15.88 & 40.60 & 6.47 \\
\hline \multicolumn{6}{|c|}{$\left[\mathrm{Sm}(\mathrm{nal})_{3}\right] \cdot 6 \mathrm{H}_{2} \mathrm{O}$} \\
\hline$\theta / \mathrm{K}$ & $298-426$ & $511-573$ & $573-712$ & $712-800$ & $800-1003$ \\
\hline$T_{\mathrm{p}} / \mathrm{K}$ & $354^{\mathrm{a}}$ & $557^{\mathrm{b}}$ & $688^{\mathrm{b}}$ & $773^{\mathrm{b}}$ & - \\
\hline$\Delta m / \%$ & 11.27 & 14.28 & 16.74 & 37.85 & 2.10 \\
\hline
\end{tabular}

${ }^{\mathrm{a}}$ Endo; ${ }^{\mathrm{b}}$ Exo 
Table 3 Experimental spectroscopic data for sodium nalidixate and its trivalent lanthanides compounds

\begin{tabular}{lllllll}
\hline Compounds & $v(\mathrm{OH}) / \mathrm{cm}^{-1}$ & $v(\mathrm{C}=\mathrm{O})^{\mathrm{a}} / \mathrm{cm}^{-1}$ & $v(\mathrm{C}=\mathrm{O})^{\mathrm{b} / \mathrm{cm}^{-1} / \mathrm{s}}$ & $v_{\mathrm{as}}\left(\mathrm{COO}^{-}\right)^{\mathrm{c}} / \mathrm{cm}^{-1}$ & $v_{\mathrm{s}}\left(\mathrm{COO}^{-}\right)^{\mathrm{d} / \mathrm{cm}^{-1}}$ & $\Delta v\left(\mathrm{COO}^{-}\right)^{\mathrm{e}} / \mathrm{cm}^{-1}$ \\
\hline $\mathrm{H}$ nal & $3423 / 3416 / 3408 \mathrm{vw}$ & $1707 \mathrm{~s}$ & 1614 & - & - & - \\
$\mathrm{Na} n a l \cdot \mathrm{H}_{2} \mathrm{O}$ & $3066-2871 \mathrm{w}$ & - & 1621 & $1583 \mathrm{~s}$ & $1343 \mathrm{~m}$ & 240 \\
{$\left[\mathrm{La}(\text { nal })_{3}\right] \cdot 5 \mathrm{H}_{2} \mathrm{O}$} & $3393 \mathrm{br}$ & - & 1614 & $1568 \mathrm{~s}$ & $1346 \mathrm{~m}$ & 222 \\
{$\left[\mathrm{Ce}(\text { nal })_{3}\right] \cdot 6 \mathrm{H}_{2} \mathrm{O}$} & $3398 \mathrm{br}$ & - & 1614 & $1566 \mathrm{~s}$ & $1346 \mathrm{~m}$ & 220 \\
{$\left[\mathrm{Pr}(\text { nal })_{3}\right] \cdot 6 \mathrm{H}_{2} \mathrm{O}$} & $3405 \mathrm{br}$ & - & 1615 & $1567 \mathrm{~s}$ & $1346 \mathrm{~m}$ & 221 \\
{$\left[\mathrm{Nd}(\text { nal })_{3}\right] \cdot 5 \mathrm{H}_{2} \mathrm{O}$} & $3375 \mathrm{br}$ & - & 1615 & $1564 \mathrm{~s}$ & $1345 \mathrm{~m}$ & 219 \\
{$\left[\mathrm{Sm}(\text { nal })_{3}\right] \cdot 6 \mathrm{H}_{2} \mathrm{O}$} & $3393 \mathrm{br}$ & - & 1615 & $1567 \mathrm{~s}$ & $1346 \mathrm{~m}$ & 221 \\
\hline
\end{tabular}

nal nalidixate, $v w$ very weak, $w$ weak, $b r$ broad, $s$ strong, $m$ medium

${ }^{\mathrm{a}} v(\mathrm{C}=\mathrm{O})$ carboxylic group

${ }^{\mathrm{b}} v(\mathrm{C}=\mathrm{O})$ ketonic group

${ }^{c} v_{\text {as }}\left(\mathrm{COO}^{-}\right)$antisymmetric carboxyl stretching frequency

${ }^{\mathrm{d}} v_{\mathrm{s}}\left(\mathrm{COO}^{-}\right)$symmetric carboxyl stretching frequency

${ }^{\mathrm{e}} \Delta v$, difference between $v_{\mathrm{as}}\left(\mathrm{COO}^{-}\right)$and $v_{\mathrm{s}}\left(\mathrm{COO}^{-}\right)$frequencies

\section{Cerium nalidixate}

The TG-DTA curves are shown in Fig. 2b. The first step of mass loss between 301 and $432 \mathrm{~K}$ is related to dehydration of $6 \mathrm{H}_{2} \mathrm{O}$ (Calc.: $11.48 \%$; TG: $11.69 \%$ ), corresponding to the endothermic peak at $371 \mathrm{~K}$ in the DTA curve.

The anhydrous compound is thermally stable up to $497 \mathrm{~K}$. Above this temperature, the final decomposition takes place in a single step up to $724 \mathrm{~K}$, corresponding to the exothermic peak at $685 \mathrm{~K}$ attributed to the oxidation reaction of $\mathrm{Ce}(\mathrm{III})$ to $\mathrm{Ce}(\mathrm{IV})$ together with the oxidation of the organic matter. This smaller thermal stability has already been observed for other kinds of cerium compounds [37-39]. The total mass loss up to $724 \mathrm{~K}$ (Calcd. $=70.25 \%$; $\mathrm{TG}=69.52 \%)$ is in agreement with the formation of $\mathrm{CeO}_{2}$, as final residue (Calcd. $=18.27 \%$; $\mathrm{TG}=18.79 \%$ ).

\section{Praseodymium nalidixate}

The TG-DTA curves are shown in Fig. 2c. The first mass loss in the range of $303-453 \mathrm{~K}$, corresponding to the endothermic peak at $378 \mathrm{~K}(\mathrm{Pr})$, is due to dehydration with loss of $6 \mathrm{H}_{2} \mathrm{O}$ (Calcd. $\left.=11.47 \%, \mathrm{TG}=10.93 \%\right)$. The anhydrous compound is thermally stable up to $500 \mathrm{~K}$; above this temperature, the mass loss occurs in three consecutive and/or overlapping steps between 500-570, $570-701$, and 701-802 K, with mass losses of 21.59, 14.62 , and $34.79 \%$, respectively. Corresponding with the mass losses of the TG curves, the DTA curves show exothermic peaks at 559, 685, and $766 \mathrm{~K}$, which are attributed to the thermal decomposition and oxidation of the organic material. The total mass loss up to $933 \mathrm{~K}$ is in agreement with formation of $\operatorname{Pr}_{6} \mathrm{O}_{11}$ (Calcd. $=18.06 \%$, $\mathrm{TG}=18.07 \%)$ as final residue.

For the compounds ( $\mathrm{La}, \mathrm{Pr}, \mathrm{Nd}$, and $\mathrm{Sm}$ ), a relationship can be observed between the thermal stability and the lanthanide ionic radius. The thermal stability increases [498 K (La), $500 \mathrm{~K}(\mathrm{Pr}), 505 \mathrm{~K}(\mathrm{Nd})$, and $511 \mathrm{~K}(\mathrm{Sm})$ ] as the ionic radius of the lanthanide ions decreases; a similar behavior was observed by Daiguebonne et al. [40] and by Matias et al. in a recent work [41]. This characteristic is due to the reduction in basicity degree of the lanthanide ions, which is a consequence of lanthanide contraction.

Table 2 provides details of the thermal events (mass losses, temperature intervals, and peak temperatures), for the simultaneous TG-DTA curves of the compounds presented in Fig. 2.

\section{XRD}

The X-ray powder patterns (Figure 1S-Supplementary Material) indicate that all the trivalent lanthanide compounds were obtained with low crystalline degree. This feature is undoubtedly due to the low solubility of the compounds and because the stirring and/or the adding velocity of the ligand solution to the respective metal chloride was not rigorously controlled, as already observed for other compounds [42, 43].

\section{Spectroscopic characterization}

The infrared spectroscopic data on nalidixic acid, sodium nalidixate, and the nalidixate compounds with trivalent lanthanide ions considered in this work are shown in Table 3, and their respective spectra can be seen in Fig. 3 . The infrared spectra of nalidixic acid indicate three 


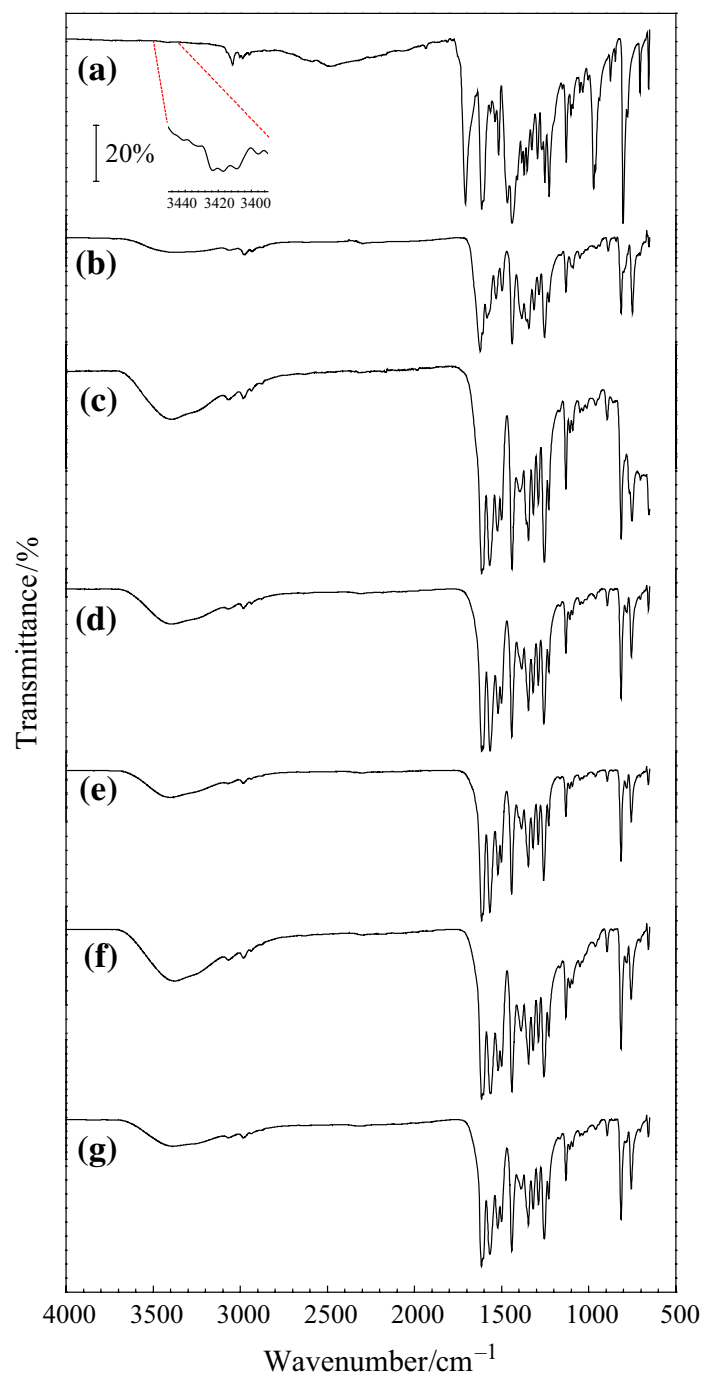

Fig. 3 FTIR spectra of the nalidixic acid, sodium nalidixate, and the light trivalent lanthanides: (a) $\mathrm{Hnal}$, (b) $\mathrm{Nanal} \cdot \mathrm{H}_{2} \mathrm{O}$, (c) $\left[\mathrm{La}(\mathrm{nal})_{3}\right]$. $5 \mathrm{H}_{2} \mathrm{O}$, (d) $\left[\mathrm{Ce}(n a l)_{3}\right] \cdot 6 \mathrm{H}_{2} \mathrm{O}$, (e) $\left[\operatorname{Pr}(n a l)_{3}\right] \cdot 6 \mathrm{H}_{2} \mathrm{O}$, (f) $\left[\mathrm{Nd}(n a l)_{3}\right] \cdot 5 \mathrm{H}_{2} \mathrm{O}$ and $(\mathrm{g})\left[\mathrm{Sm}(\mathrm{nal})_{3}\right] \cdot 6 \mathrm{H}_{2} \mathrm{O}$

imperceptible absorptions (visible only in a magnified view), due to $v(\mathrm{O}-\mathrm{H})$ stretching vibration of $\mathrm{OH}$ in the $\mathrm{COOH}$ group at $3423.4,3416.9$, and $3408.5 \mathrm{~cm}^{-1}$. Two other very strong absorptions are at $1707 \mathrm{~cm}^{-1}$, due to $v(\mathrm{C}=\mathrm{O})$ stretching vibration of the carboxylic group, and at $1614 \mathrm{~cm}^{-1}$, which is attributed to the $v(\mathrm{C}=\mathrm{O})$ of the keto group in pyridine ring $[44,45]$.

The sodium salt and the trivalent lanthanide complexes have no absorption band at $1717 \mathrm{~cm}^{-1} v(\mathrm{C}=\mathrm{O})$, which is indicative of the deprotonation of carboxylic group and involvement of the carboxylate group in the metal coordination. The spectra of the complexes show two characteristic bands between $1568-1564$ and $1346-1343 \mathrm{~cm}^{-1}$ for $\mathrm{La}(\mathrm{III})$ to $\mathrm{Sm}$ (III) complexes, assigned as antisymmet- ric $\left(v_{\text {as }}\left(\mathrm{COO}^{-}\right)\right)$and symmetric $\left(v_{\mathrm{s}}\left(\mathrm{COO}^{-}\right)\right)$carboxylate stretching frequencies, respectively $[44,45]$.

The values of $\Delta v\left(v_{\mathrm{as}} \mathrm{COO}^{-}-v_{\mathrm{s}} \mathrm{COO}^{-}\right.$, carboxylate vibrations) for the synthesized compounds are a little less than those calculated for the sodium salt (Table 3), suggesting that the coordination is carried out through the carboxylate group of the nalidixate in a bidentate mode (chelating ligand) [46-48]. On the other hand, the absorption frequencies attributed to the stretching of the carbonyl ketone group in the lanthanide complexes are very similar to that of the free ligand (Hnal), which indicates that this group should not be participating in the coordination. The great similarity between the spectra for the complexes suggests that all are coordinated in the same way.

The near infrared region (NIR) spectra in Fig. 4 of the sodium salt, the acid ligand, and compounds with the trivalent lanthanides provided information about the combination and overtone bands of the compounds. Characteristic water bands appear only in the spectra of the complexes $\left(\sim 6900\right.$ and $\left.5130 \mathrm{~cm}^{-1}\right)$, in agreement with the TG-DSC results. Characteristic bands of carboxylic acid $\left(\sim 6655\right.$ and $\left.5210 \mathrm{~cm}^{-1}\right)$ only appear in the acid form, which confirm the total deprotonation and the absence of acid contamination in the sodium salt and in the complexes.

Electronic transitions of the complexes were studied in the ultraviolet, visible, and near infrared regions. The diffuse reflectance (DR) spectra $(200-1000 \mathrm{~nm})$ of the acid ligand and $\mathrm{Ln}(\mathrm{III})$ complexes $(\mathrm{Ln}=\mathrm{La}, \mathrm{Ce}, \mathrm{Pr}, \mathrm{Nd}$, and $\mathrm{Sm})$ are presented in Fig. $2 \mathrm{~S}$ on the Supplementary Material. The spectra of the ligand (Figure $2 \mathrm{~S}$-Supplementary Material) exhibit a broad intra-ligand (IL) band in the UV and visible region $(200-380 \mathrm{~nm})$. After the coordination with the $\operatorname{Ln}(\mathrm{III})$ ions, a less intense band appears in the 380-480 $\mathrm{nm}$ region, due to the changes in the chemical environment. The spectra of $\operatorname{Pr}(\mathrm{III}), \mathrm{Nd}(\mathrm{III})$, and $\mathrm{Sm}$ (III) also show the typical absorption bands due to $4 f-4 f$ transitions from the ground states to the excited ones of the $\mathrm{Ln}$ (III) ions in the visible spectral range.

Lanthanum complex does not present electronic transitions in this region, because its core electronic structure has filled shells: Thus, high energies are necessary to promote an electron from these filled shells. The Ce(III) ion presents characteristic bands in the UV region related to $4 f-$ $5 d$ transitions, but rarely appears in complexes, due to the overlap of the ligand bands [49]. Moreover, a broad and intense band appears in the $400-635 \mathrm{~nm}$ spectral range of the Ce(III) complex, probably due a metal-to-ligand charge transfer (MLCT) band [50]. The absorption spectra of the praseodymium complex show peaks corresponding to the 
Fig. 4 Near infrared spectra of a Hnal, b Nanal $\cdot \mathrm{H}_{2} \mathrm{O}$,

c $\left[\mathrm{La}(\mathrm{nal})_{3}\right] \cdot 5 \mathrm{H}_{2} \mathrm{O}$,

d $\left[\mathrm{Ce}(n a l)_{3}\right] \cdot 6 \mathrm{H}_{2} \mathrm{O}$,

e $\left[\operatorname{Pr}(n a l)_{3}\right] \cdot 6 \mathrm{H}_{2} \mathrm{O}$,

f $\left[\mathrm{Nd}(n a l)_{3}\right] \cdot 5 \mathrm{H}_{2} \mathrm{O}$, and

g $\left[\mathrm{Sm}(\mathrm{nal})_{3}\right] \cdot 6 \mathrm{H}_{2} \mathrm{O}$. The dashed lines in $\mathbf{e}, \mathbf{g}$ refer to the lanthanum complex spectrum, which evidenciates the $f-$ $f$ transitions (a)
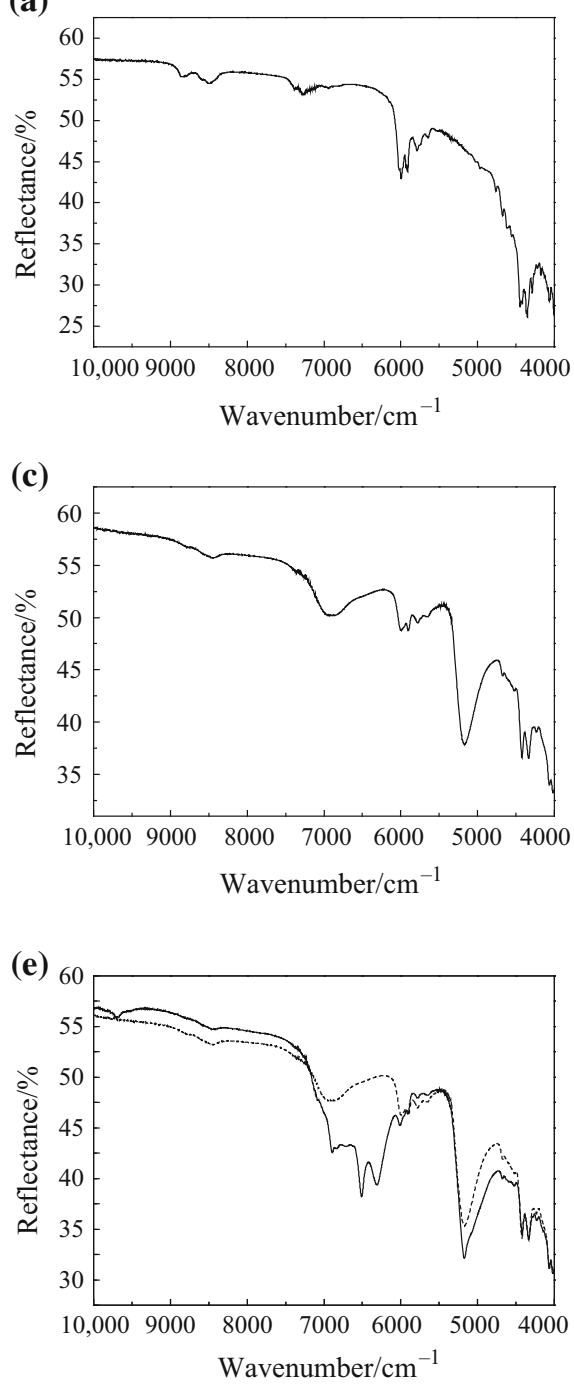

(b)

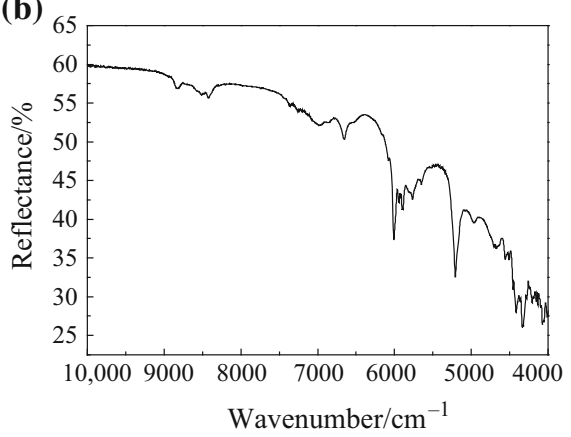

(d)

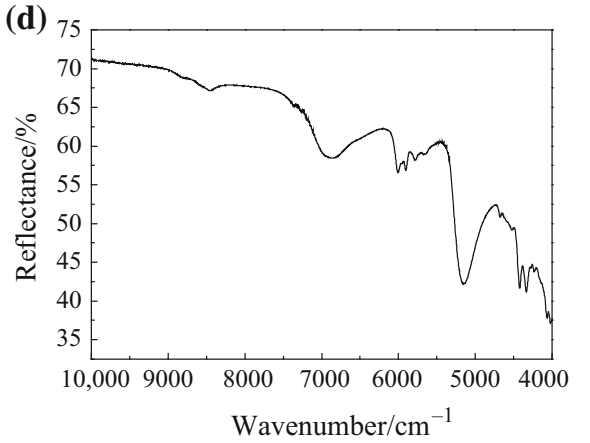

(f)

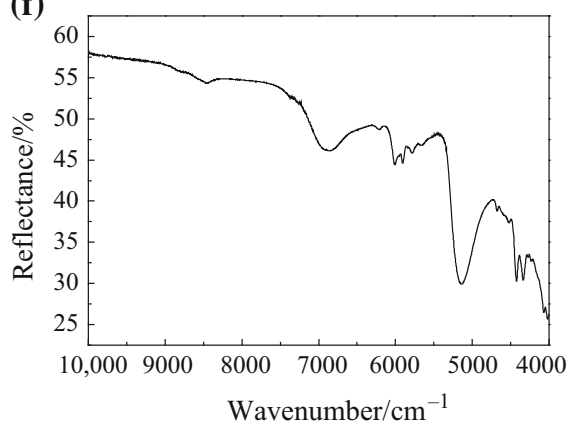

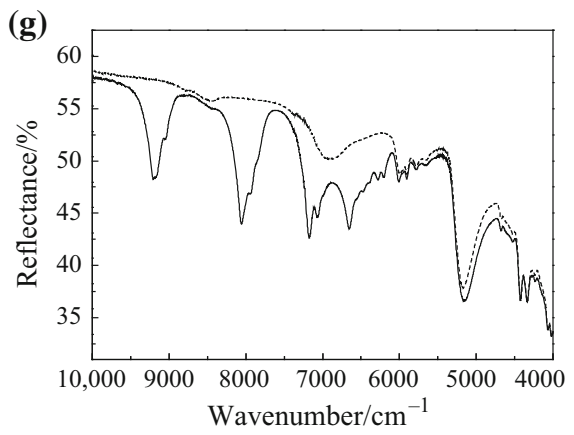

transitions from the ${ }^{3} \mathrm{H}_{4}$ ground state to the excited states. Characteristic absorption bands are also observed in the spectra of the neodymium complex within this spectral range due to transitions from the ${ }^{4} \mathrm{I}_{9 / 2}$ ground state to the excited states. Samarium complex spectra show peaks that correspond to the transitions from the ${ }^{6} \mathrm{H}_{5 / 2}$ ground state to the excited states. The NIR spectra of praseodymium and samarium complexes also exhibit bands that were assigned to $f-f$ transitions. These peaks are presented in Table 4 with the assignment of transitions. 
Table 4 Absorption bands of the $f-f$ transitions in visible and near infrared regions of the praseodymium, neodymium, and samarium complexes

\begin{tabular}{|c|c|c|c|}
\hline Compound & Wavenumber $/ \mathrm{cm}^{-1}$ & Wavelength/nm & Assignments \\
\hline \multirow[t]{9}{*}[\operatorname{Pr}(nal)_{3}]{$\cdot 6 \mathrm{H}_{2} \mathrm{O}$} & 22,422 & 446 & ${ }^{3} \mathrm{H}_{4} \rightarrow{ }^{3} \mathrm{P}_{2}$ \\
\hline & 21,231 & 471 & ${ }^{3} \mathrm{H}_{4} \rightarrow{ }^{3} \mathrm{P}_{1},{ }^{1} \mathrm{I}_{6}$ \\
\hline & 20,661 & 484 & ${ }^{3} \mathrm{H}_{4} \rightarrow{ }^{3} \mathrm{P}_{0}$ \\
\hline & $17,036,16,835,16,556$ & $587,594,604$ & ${ }^{3} \mathrm{H}_{4} \rightarrow{ }^{1} \mathrm{D}_{2}$ \\
\hline & 9704 & 1031 & ${ }^{3} \mathrm{H}_{4} \rightarrow{ }^{1} \mathrm{G}_{4}$ \\
\hline & 6898 & 1450 & ${ }^{3} \mathrm{H}_{4} \rightarrow{ }^{3} \mathrm{~F}_{4}$ \\
\hline & 6503 & 1538 & ${ }^{3} \mathrm{H}_{4} \rightarrow{ }^{3} \mathrm{~F}_{3}$ \\
\hline & 5174 & 1933 & ${ }^{3} \mathrm{H}_{4} \rightarrow{ }^{3} \mathrm{~F}_{2}^{*}$ \\
\hline & 21,231 & 471 & ${ }^{3} \mathrm{H}_{4} \rightarrow{ }^{3} \mathrm{P}_{1},{ }^{1} \mathrm{I}_{6}$ \\
\hline \multirow[t]{12}{*}[\mathrm{Nd}(nal)_{3}]{$\cdot 5 \mathrm{H}_{2} \mathrm{O}$} & 23,310 & 429 & ${ }^{4} \mathrm{I}_{9 / 2} \rightarrow{ }^{2} \mathrm{P}_{1 / 2}$ \\
\hline & 21,739 & 460 & ${ }^{4} \mathrm{I}_{9 / 2} \rightarrow{ }^{4} \mathrm{G}_{11 / 2}$ \\
\hline & 21,186 & 472 & ${ }^{4} \mathrm{I}_{9 / 2} \rightarrow{ }^{2} \mathrm{G}_{9 / 2},{ }^{2} \mathrm{D}_{3 / 2},{ }^{2} \mathrm{P}_{3 / 2}$ \\
\hline & 20,877 & 479 & ${ }^{4} \mathrm{I}_{9 / 2} \rightarrow{ }^{2} \mathrm{~K}_{15 / 2}$ \\
\hline & 19,531 & 512 & ${ }^{4} \mathrm{I}_{9 / 2} \rightarrow{ }^{4} \mathrm{G}_{9 / 2}$ \\
\hline & 19,011 & 526 & ${ }^{4} \mathrm{I}_{9 / 2} \rightarrow{ }^{4} \mathrm{G}_{7 / 2}^{*}$ \\
\hline & 17,182 & 582 & ${ }^{4} \mathrm{I}_{9 / 2} \rightarrow{ }^{4} \mathrm{G}_{5 / 2}^{*},{ }^{2} \mathrm{G}_{7 / 2}$ \\
\hline & 15,923 & 628 & ${ }^{4} \mathrm{I}_{9 / 2} \rightarrow{ }^{2} \mathrm{H}_{11 / 2}$ \\
\hline & 14,620 & 684 & ${ }^{4} \mathrm{I}_{9 / 2} \rightarrow{ }^{4} \mathrm{~F}_{9 / 2}$ \\
\hline & $13,569,13,458,13,315$ & $737,743,751$ & ${ }^{4} \mathrm{I}_{9 / 2} \rightarrow{ }^{4} \mathrm{~F}_{7 / 2},{ }^{2} \mathrm{~S}_{3 / 2}$ \\
\hline & 12,438 & 804 & ${ }^{4} \mathrm{I}_{9 / 2} \rightarrow{ }^{4} \mathrm{~F}_{5 / 2}^{*},{ }^{2} \mathrm{H}_{9 / 2}^{*}$ \\
\hline & 11,429 & 875 & ${ }^{4} \mathrm{I}_{9 / 2} \rightarrow{ }^{4} \mathrm{~F}_{3 / 2}$ \\
\hline \multirow[t]{17}{*}[\mathrm{Sm}(nal)_{3}]{$\cdot 6 \mathrm{H}_{2} \mathrm{O}$} & 24,814 & 403 & ${ }^{6} \mathrm{H}_{5 / 2} \rightarrow{ }^{4} \mathrm{~L}_{13 / 2}+{ }^{4} \mathrm{~F}_{7 / 2}$ \\
\hline & 23,923 & 418 & ${ }^{6} \mathrm{H}_{5 / 2} \rightarrow{ }^{6} \mathrm{P}_{9 / 2}+{ }^{4} \mathrm{P}_{5 / 2}$ \\
\hline & 22,727 & 440 & ${ }^{6} \mathrm{H}_{5 / 2} \rightarrow{ }^{4} \mathrm{G}_{9 / 2}+{ }^{4} \mathrm{I}_{15 / 2}$ \\
\hline & 22,173 & 451 & ${ }^{6} \mathrm{H}_{5 / 2} \rightarrow{ }^{4} \mathrm{~F}_{5 / 2}$ \\
\hline & 21,551 & 464 & ${ }^{6} \mathrm{H}_{5 / 2} \rightarrow{ }^{4} \mathrm{I}_{13 / 2}$ \\
\hline & 21,053 & 475 & ${ }^{6} \mathrm{H}_{5 / 2} \rightarrow{ }^{4} \mathrm{I}_{11 / 2}$ \\
\hline & 20,833 & 480 & ${ }^{6} \mathrm{H}_{5 / 2} \rightarrow{ }^{4} \mathrm{M}_{15 / 2}+{ }^{4} \mathrm{I}_{9 / 2}$ \\
\hline & 20,080 & 498 & ${ }^{6} \mathrm{H}_{5 / 2} \rightarrow{ }^{4} \mathrm{G}_{7 / 2}$ \\
\hline & 18,903 & 529 & ${ }^{6} \mathrm{H}_{5 / 2} \rightarrow{ }^{4} \mathrm{~F}_{3 / 2}$ \\
\hline & 17,857 & 560 & ${ }^{6} \mathrm{H}_{5 / 2} \rightarrow{ }^{4} \mathrm{G}_{5 / 2}$ \\
\hline & 10,526 & 950 & ${ }^{6} \mathrm{H}_{5 / 2} \rightarrow{ }^{6} \mathrm{~F}_{11 / 2}$ \\
\hline & 9181 & 1089 & ${ }^{6} \mathrm{H}_{5 / 2} \rightarrow{ }^{6} \mathrm{~F}_{9 / 2}$ \\
\hline & 8057 & 1241 & ${ }^{6} \mathrm{H}_{5 / 2} \rightarrow{ }^{6} \mathrm{~F}_{7 / 2}$ \\
\hline & 7173 & 1394 & ${ }^{6} \mathrm{H}_{5 / 2} \rightarrow{ }^{6} \mathrm{~F}_{5 / 2}$ \\
\hline & 6653 & 1503 & ${ }^{6} \mathrm{H}_{5 / 2} \rightarrow{ }^{6} \mathrm{~F}_{3 / 2}^{*}$ \\
\hline & 6481 & 1543 & ${ }^{6} \mathrm{H}_{5 / 2} \rightarrow{ }^{6} \mathrm{H}_{15 / 2}$ \\
\hline & 6281 & 1592 & ${ }^{6} \mathrm{H}_{5 / 2} \rightarrow{ }^{6} \mathrm{~F}_{1 / 2}^{*}$ \\
\hline
\end{tabular}

\section{Conclusions}

Supported by the TG data, elemental analysis, and result of complexometric titrations, a general formula $\left[\operatorname{Ln}(\mathrm{nal})_{3}\right]$. $n \mathrm{H}_{2} \mathrm{O}$ could be established, where $\mathrm{Ln}$ is the trivalent lanthanide ions (La to $\mathrm{Sm}$ ), nal is the nalidixate ligand, and $n$ is the number of hydration molecules of water, which are $5(\mathrm{Nd}), 5(\mathrm{La})$, and 6 (Ce, Pr and Sm). The TG curve shows that dehydration occurs in a single step and the anhydrous complexes are stable between $497 \mathrm{~K}(\mathrm{Ce})$ and $511 \mathrm{~K}(\mathrm{Sm})$, which are the lowest and highest temperatures between the compounds. The TG-DTA and DSC provided unreported information concerning the thermal behavior and thermal decomposition of this complex. The thermal analysis was also important to demonstrate the effect of the ionic radius of lanthanide ions in the dehydration temperature and thermal stability of the compounds. The X-ray powder diffraction shows that the complexes are obtained in a low crystalline degree. The spectroscopic characterization provides information about the coordination mode of the 
ligand to the trivalent lanthanide ions, suggesting that nalidixate acts in a bidentate way (chelating mode) only by the carboxylate group. The electronic spectra indicate the changes in the chemical environment after the coordination and provide information about the $4 f-4 f$ transitions of the $\operatorname{Pr}(\mathrm{III}), \mathrm{Nd}(\mathrm{III})$, and $\mathrm{Sm}(\mathrm{III})$ ions.

Acknowledgements The authors thank PROPe-UNESP (Proc. 0109/008/13-PROPe/CDC), FAPESP (Proc. 2006/06951-3), CAPES, and CNPq (Proc. 472233/2008-4 and 150759/2009) for financial support. This research was supported by resources supplied by the Faculdade de Engenharia de Guaratinguetá (UNESP), Instituto de Química de Araraquara (UNESP), and a special thanks to GFQM-IQ for $\mathrm{X}$ ray diffraction measurements.

\section{References}

1. Zong GC, Ren N, Zhang JJ, Qi XX, Gao J. Lanthanide complexes with 3-bromine-4-methyl benzoic acid and 1,10-phenanthroline: synthesis, crystal structures, thermal properties and bacteriostatic activities. J Therm Anal Calorim. 2016;123:105-16.

2. Martinez-Gomez NC, Vu HN, Skovran E. Lanthanide chemistry: from coordination in chemical complexes shaping our technology to coordination in enzymes shaping bacterial metabolism. Inorg Chem. 2016;55:10083-9.

3. Wen H-R, Dong P-P, Liang F-Y, Liu S-J, Xie X-R, Tang Y-Z. A family of 2D lanthanide complexes based on flexible thiodiacetic acid with magnetocaloric or ferromagnetic properties. Inorg Chim Acta. 2017;455:190-6.

4. Wang W-M, Guan X-F, Liu X-D, Fang M, Zhang C-F, Fang M, et al. Two $\mathrm{Gd}_{2}$ compounds constructed by 8 -hydroxyquinoline Schiff base ligands: synthesis, structure, and magnetic refrigeration. Inorg Chem Commun. 2017;79:8-11.

5. Liu F, Huang H, Gao W, Zhang X, Liu J-P. 3D Ln-MOFs containing pentanuclear clusters exhibiting magnetic refrigeration and slow magnetic relaxation. CrystEngComm. 2017;19:3660-5.

6. Gao C, Hou G, Zuo D, Jiang W, Yu Y, Ma D-S, et al. Syntheses, crystal structures, magnetisms and luminescences of two series of lanthanide coordination polymers based on tricarboxylic ligand. ChemistrySelect. 2017;2:1111-6.

7. Evstifeev IS, Efimov NN, Varaksina EA, Taydakov IV, Mironov VS, Dobrokhotova ZV, et al. Thermostable 1D lanthanide 4-phenylbenzoate polymers [ $\mathrm{Ln}(4-\mathrm{phbz}) 3] \mathrm{n}(\mathrm{Ln}=\mathrm{Sm}, \mathrm{Eu}, \mathrm{Gd}$, $\mathrm{Tb}$, Dy, Ho) with isolated metal chains: synthesis, structure, luminescence, and magnetic properties. Eur $\mathbf{J}$ Inorg Chem. 2017;2017:2892-904.

8. Ghosh S, Abbas Z, Dasari S, Patra AK. Luminescent $\mathrm{Eu}^{3+}$ and $\mathrm{Tb}^{3+}$ complexes of 4-aminophenyl terpyridine (ptpy): photophysical aspects, DNA and serum protein binding properties. J Lumin. 2017; 187:46-52.

9. Akhtar MN, Chen Y-C, AlDamen MA, Tong M-L. 3D oxalatobridged lanthanide (III) MOFs with magnetocaloric, magnetic and photoluminescence properties. Dalton Trans. 2017;46:116-24

10. Wu J, Jin C, Zhang D-H, Ren N, Zhang J. A series of lanthanide complexes with 2,3-dichlorobenzoic acid and 2,2:6', $2^{\prime \prime}$-terpyridine: crystal structures, spectroscopic and thermal properties. Thermochim Acta. 2015;620:28-35.

11. Qi X-X, Wu J-C, Ren N, Zhao C-L, Zhang J-J, Zong G-C, et al. Novel lanthanide complexes constructed from 3, 4-dimethoxybenzoic acid: crystal structures, spectrum and thermochemical properties. Thermochim Acta. 2015;615:1-7.
12. Huo J-X, Wang Y, Zhang D-H, Ren N, Zhang J-J. Syntheses, characterization, luminescence, and thermal decomposition mechanism of four lanthanide complexes with 4-ethylbenzoic acid and terpyridine. J Therm Anal Calorim. 2016;124:1575-85.

13. Wang G-T, Zhang J-C, Tang Z-Y, Zhou H-T, Zhang L, Yang $\mathrm{R}-\mathrm{W}$, et al. Synthesis, structures, luminescence and magnetism of nine lanthanide complexes with three-dimensional frameworks constructed from 2-(pyridyl-N-oxide)methylphosphonic acid and oxalic acid. CrystEngComm. 2016;18:2437-45.

14. Singh K, Srivastava P, Patra AK. Binding interactions with biological targets and DNA photocleavage activity of $\operatorname{Pr}(\mathrm{III})$ and $\mathrm{Nd}(\mathrm{III})$ complexes of dipyridoquinoxaline. Inorg Chim Acta. 2016;451:73-81.

15. Sarkar T, Banerjee S, Mukherjee S, Hussain A. Mitochondrial selectivity and remarkable photocytotoxicity of a ferrocenyl neodymium(III) complex of terpyridine and curcumin in cancer cells. Dalton Trans. 2016;45:6424-38.

16. Cotton FA, Wilkinson G. Advanced inorganic chemistry-a comprehensive text. 5th ed. New York: Wiley; 1988.

17. Campos FX, Nascimento ALCS, Colman TAD, Gálico DA, Carvalho ACS, Caires FJ, et al. Thermal behavior, spectroscopic studies and free radical scavenging potential of some mefenamate trivalent lanthanides (Sm, Eu, Gd, Tb and Dy). Thermochim Acta. 2017;651:73-82.

18. Campos FX, Soares MRS, Terezo AJ, Siqueira AB. Synthesis, characterization, and antioxidant evaluation of solid-state mefenamates of some bivalent metals. J Therm Anal Calorim. 2014;115:167-76.

19. Gálico DA, Lahoud MG, Davolos MR, Frem RCG, Fraga-Silva TFC, Venturini J, et al. Spectroscopic, luminescence and in vitro biological studies of solid ketoprofen of heavier trivalent lanthanides and yttrium(III). J Inorg Biochem. 2014;140:160-6.

20. Binil PS, Anoop MR, Jisha KR, Suma S, Sudarsanakumar MR. Synthesis, spectral characterization, thermal and biological studies of lanthanide(III) complexes of oxyphenbutazone. J Rare Earths. 2014;32:43-51.

21. Lin J, Xu X, Zhou W, Yu L, Wang Q. Easy assembly of visible light excited lanthanide containing edifices and structural origin. Dyes Pigments. 2015;119:56-61.

22. Zhou X, Zhao X, Wang Y, Wu B, Shen J, Li L, et al. Eu(III) and $\mathrm{Tb}$ (III) complexes with the nonsteroidal anti-inflammatory drug carprofen: synthesis, crystal structure, and photophysical properties. Inorg Chem. 2014;53:12275-82.

23. Singha S, Ahn K. Detection of ciprofloxacin in urine through sensitized lanthanide luminescence. Sensors. 2016;16:2065.

24. Kostova I, Momekov G, Tzanova T, Karaivanova M. Synthesis, characterization, and cytotoxic activity of new lanthanum(III) complexes of bis-coumarins. Bioinorg Chem Appl. 2006;2006:1-9.

25. Kostova I, Traykova M, Rastogi VK. New lanthanide complexes with antioxidant activity. Med Chem (Los Angeles). 2008;4:371-8.

26. Chen ZN, Deng RW, Wu JG. Synthesis, characterization, and antiinflammatory activity of naproxen complexes with rare earth (III). J Inorg Biochem. 1992;47:81-7.

27. Refat MS, Al-Maydama HMA, Al-Azab FM, Amin RR, Jamil YMS. Synthesis, thermal and spectroscopic behaviors of metaldrug complexes: $\mathrm{La}(\mathrm{III}), \mathrm{Ce}(\mathrm{III}), \mathrm{Sm}(\mathrm{III})$ and $\mathrm{Y}(\mathrm{III})$ amoxicillin trihydrate antibiotic drug complexes. Spectrochim Acta Part A. 2014;128:427-46.

28. Aggarwal N, Kumar R, Dureja P, Khurana JM. Synthesis, antimicrobial evaluation and QSAR analysis of novel nalidixic acid based 1,2,4-triazole derivatives. Eur J Med Chem. 2011:46:4089-99.

29. Uivarosi V. Metal complexes of quinolone antibiotics and their applications: an update. Molecules. 2013;18:11153-97. 
30. Sekhon BS, Gandhi L. Synthesis and characterization of metal complexes of some antibacterial drugs. Int J Chemtech Res. 2010;2:286-8.

31. Psomas G, Kessissoglou DP. Quinolones and non-steroidal antiinflammatory drugs interacting with copper(II), nickel(II), cobalt(II) and zinc(II): structural features, biological evaluation and perspectives. Dalton Trans. 2013;42:6252-76.

32. Eliseeva SV, Liasotkyi VS, Golovach IP, Doga PG, Antonovich VP, Petoud S, et al. Exploring the ability of the nalidixate to sensitize visible and near-infrared emitting lanthanide(III) cations. Methods Appl Fluoresc. 2017;5:14002.

33. Ionashiro M, Graner CAF, Netto JZ, Zuanon-Netto J. Titulação complexométrica de lantanídeos e ítrio. Eclética Química. 1983;8:29-32.

34. Flaschka HA. EDTA titrations: an introduction to theory and practice. 2nd ed. Oxford: Pergamon Press; 1964.

35. Lahoud MG, Frem RCG, Gálico DA, Bannach G, Nolasco MM, Ferreira RAS, Carlos LD. Intriguing light-emission features of ketoprofen-based $\mathrm{Eu}(\mathrm{III})$ adduct due to a strong electron-phonon coupling. J Lumin. 2016;170:357-63.

36. Gálico DA, Fraga-Silva TFC, Venturini J, Bannach G. Thermal, spectroscopic and in vitro biological studies of the lanthanum complex of naproxen. Thermochim Acta. 2016;644:43-9.

37. D'Assunção LM, Giolito I, Ionashiro M. Thermal decomposition of the hydrated basic carbonates of lanthanides and yttrium. Thermochim Acta. 1989;137:319-30.

38. Miyano MH, Melios CB, Ribeiro CA, Redigolo H, Ionashiro M. The preparation and thermal decomposition of solid state compounds of 4-dimethylaminobenzylidenepyruvate and trivalent lanthanides and yttrium. Thermochim Acta. 1993;221:53-62.

39. Oliveira LCS, Melios CB, Crespi MS, Ribeiro CA, Ionashiro M. Preparation and thermal decomposition of solid state compounds of 4-methoxybenzylidenepyruvate and trivalent lanthanides and yttrium. Thermochim Acta. 1993;219:215-24.

40. Daiguebonne C, Kerbellec N, Guillou O, Bünzli J-C, Gumy F, Catala L, et al. Structural and luminescent properties of microand nanosized particles of lanthanide terephthalate coordination polymers. Inorg Chem. 2008;47:3700-8.
41. Matias FRM, da Silva VMF, Nunes RS. Luiz JM. Synthesis, characterization and thermal behavior of some trivalent lanthanide 4-amino-benzenesulfonate salts. J Therm Anal Calorim. 2017;130:2185-90.

42. Bannach G, Schnitzler E, Treu-Filho O, Utuni VHS, Ionashiro M. Synthesis, characterization and thermal studies on solid compounds of 2-chlorobenzylidenepyruvate of heavier trivalent lanthanides and yttrium(III). J Therm Anal Calorim. 2006;83:233-40.

43. Bannach G, de Siqueira AB, Ionashiro EY, Rodrigues EC, Ionashiro M. Solid-state compounds of 2-chlorobenzylidenepyruvate with some bivalent metal ions: synthesis, characterization and thermal behaviour. $\mathrm{J}$ Therm Anal Calorim. 2007;90:873-9.

44. Zaky M, El-Sayed MY, El-Megharbel SM, Abo Taleb S, Refat MS. Complexes of nalidixic acid with some vital metal ions: synthesis, chemical structure elucidation, and antimicrobial evaluation. Russ J Gen Chem. 2013;83:2488-501.

45. Debnath A, Mogha NK, Masram DT. Metal complex of the firstgeneration quinolone antimicrobial drug nalidixic acid: structure and its biological evaluation. Appl Biochem Biotechnol. 2015;175:2659-67.

46. Sutton CCR, Da Silva G, Franks GV. Modeling the IR spectra of aqueous metal carboxylate complexes: correlation between bonding geometry and stretching mode wavenumber shifts. Chem A Eur J. 2015;21:6801-5.

47. Deacon GB, Huber F, Phillips RJ. Diagnosis of the nature of carboxylate coordination from the direction of shifts of carbonoxygen stretching frequencies. Inorg Chim Acta. 1985;104:41-5.

48. Deacon GB, Phillips RJ. Relationships between the carbon-oxygen stretching frequencies of carboxylato complexes and the type of carboxylate coordination. Coord Chem Rev. 1980;33:227-50.

49. Sastri VS, Bünzli J-CG, Rao VR, Rayudu GVS, Perumareddi JR. Spectroscopy of lanthanide complexes. In: Modern aspects of rare earths and their complexes. Elsevier Science; 2003. p. 569-731.

50. Vogler A, Kunkely H. Excited state properties of lanthanide complexes: beyond ff states. Inorg Chim Acta. 2006;359:4130-8. 